専門医症例報告

上下顎の高度な顎堤吸収患者の有床義歯補綴症例

上濱 正

\title{
A Prosthetic Removable Denture with Severe Bone Resorption in Maxilla and Mandible
}

Akira Uehama

抄 録

症例の概要：69 歳女性。半年前に装着した上顎左側 2 臼歯根面に付与した磁性アタッチメント応用のオ ーバーデンチャーおよび下顎部分義歯の維持・安定が得られず咀嚼障害と審美障害を主訴として来院した. 考察：治療用義歯装着 6 力月後上顎の維持・安定, 下顎位の安定が図られ咀嚼障害, 審美障害が改善した ので上顎に総義歯を新製した。 6 カ月間隔でメインテナンスを行い，現在 3 年経過したがきわめて良好な 経過をたどっている。

結論 : 本症例は，デンチャースペースの回復と口腔周囲筋および舌の機能時における形態が上下顎義歯と 調和し良好な経過を得ている。

和文キーワード

オーバーデンチャー，部分床義歯，治療用義歯，デンチャースペース，コンビネーションシンドローム

\section{ABSTRACT}

Patient: A 69-year-old woman presented with the chief complaints being instability and esthetic and chewing problems associated with dentures fitted six months previously. The dentures had magnetic attachment overdenture for maxilla and RPD for mandible.

Discussion: We made a new complete denture on the maxilla six months after the initial treatment denture, and we achieved good stability in both the maxilla and mandible, as well as improved chewing and esthetic issues. The situation has been monitored regularly at six month intervals and three years after initial prognosis the complete denture continues to function effectively.

Conclusion: There has been progress by a well-balanced gained denture space in terms of oral muscles and tongue movement.

\section{Key words}

overdenture, partial denture, treatment denture, denture space, combination syndrome 


\section{I. 緒言}

高度な顎堤吸収患者の有床義歯補経症例は，顎堤の形 態，性状から義歯の維持・安定を図ることが困難な場合 が多く, 咀嚼障害や審美障害を訴えることがある、本症 例は, 義歯の維持・安定, 咬合高径を回復するためにデ ンチャースペースと形態とを十分に考慮したところ，咀 嚼障害，審美障害が明らかに改善したので報告する。

\section{II. 症例の概要}

患者：69 歳, 女性（初診時）。

初診日: 平成 18 年 4 月 12 日。

主訴 : 食事時の上顎䫈堤の疼痛と上顎義歯の脱離の必 発，著明な口唇周囲のしわ。

全身的既往歴：左膝の骨折 (6 年前).

現病歴：約半年前に装着した歯根面（上6 7 ）に付与 した磁性アタッチメント応用の上顎オーバーデンチャー と下顎両側遊離端義歯を装着したが, 装着直後から維持・ 安定が得られず，担当医より当院を紹介され来院した。

現症および問題点：上顎の顎堤は高度な顎堤吸収（左 右非対称）と前歯部顎堤のフラビーガムを認め，歯槽堤 弓は上顎前歯部が下顎のアーチよりも約 $10 \mathrm{~mm}$ 後退 （切歯窩が露出）している. 下顎残存歯は $32 \mid 23$ であ り, 軽度の慢性辺縁性歯周炎に罹患している。下顎臼歯 部も高度な顎堤吸収（オトガイ孔，顎舌骨筋付着部の露 出）を認める. 顔貌は上下口唇面積の不一致, 口角のし わを認め, 顔面計測にて約 $4 \mathrm{~mm}$ の低位咬合を認める。 上顎旧義歯は 67 相当部に磁性アタッチメント付根面 板が付与されたレジン製のオーバーデンチャーが，下顎 義歯は $32 \mid 23$ にそれぞれ両翼鉤が付与されたレジン 製の部分床義歯が装着されていた。上下顎ともにデンチ ヤースペースが狭く，下顎義歯の㚘側に空隙が，舌側の 舌房の狭小による舌の運動障害が認められた。また，下 顎義歯の維持・支持は不足していた（図 1).

診断：以上より上下顎の高度な顎堤吸収に起因してコ ンビネーションシンドローム ${ }^{1)}$ を起こしたことによる 咀嚼障害・審美障害と診断した。

治療方針：上下顎の本来あるべきデンチャースペース を確保し，下顎には床座面積の拡大，人工歯排列位置の 修正 (ニュートラルゾーン), 流線形の形態の付与 ${ }^{2)}$ に よる部分床義歯を装着する。上顎は口輪筋によるリップ サポートに加え㚘筋の走行形態と筋線維特性 ${ }^{3)}$ を十分 に考慮して義歯後縁を中心にデンチャースペースに適応 する形態付与を行い，粘膜面の改善と咬合高径の回復の
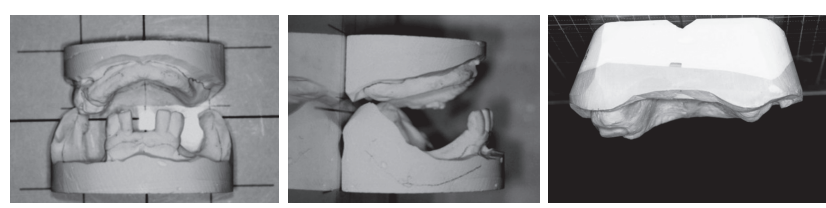

図 1 The first examination 初診時
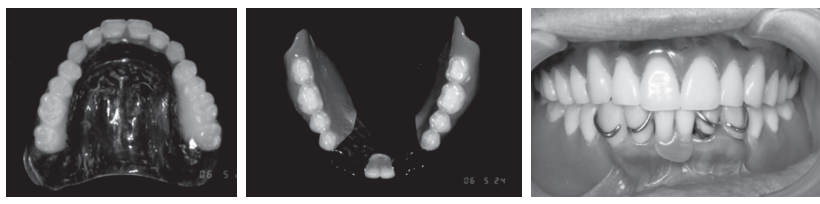

図2 Intraoral views at insertion of the treatment denture

治療用義歯装着時および口腔内装着時

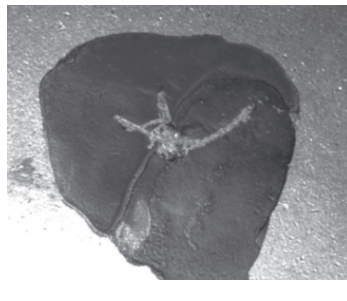

a

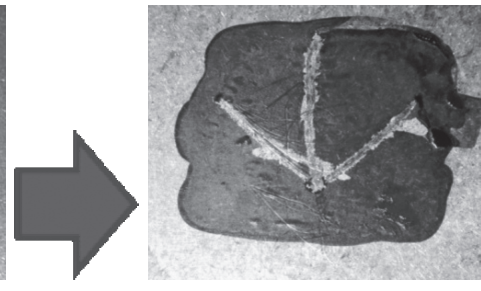

b
図 3 Gothic arch and tapping point a: before treatment, b: after treatment ゴシックアーチおよびタッピングポイント $\mathrm{a}:$ 治療前, $\mathrm{b}:$ 治療後

ために治療用義歯を応用することにした。リハビリトレ ーニングにより, 維持・支持・筋平衡・咬合平衡の確立, 下顎位の安定, 咀嚼能力の向上を求めることにした ${ }^{4)}$.

\section{III．治療内容と経過}

補経前処置として, 残存歯の歯周基本治療および TBI を行った。 その後, 上下顎ともに $10 \%$ 混水比を増した アルジネート印象材にて概形印象採得した模型上で個人 トレー（粘膜面に均一に $1.5 \mathrm{~mm}$ モデリングコンパウ ンドを裏層したもの)を製作し選択的加圧印象を行った。 咬合採得は通法に従い咬合平面を決定後，垂直的顎間関 係を，上下口唇の面積の一致，矢状鼻唇角 $95^{\circ}$ ，口角の しわ $2 \sim 3 \mathrm{~mm}$, 顔面計測法により鼻下点一オトガイ 間距離で旧義歯より $4 \mathrm{~mm}$ 拳上した。水平的顎間関係 は, 毎秒 3 回のライトタッピング, 礜下運動利用法, ゴシックアーチ描記法にて決定した。またシリコーン印 象材にて煩舌側の形態を機能圧で印記し口腔周囲筋（口 輪筋・煩筋・上咽頭収縮筋など）に調和した研磨面形態 

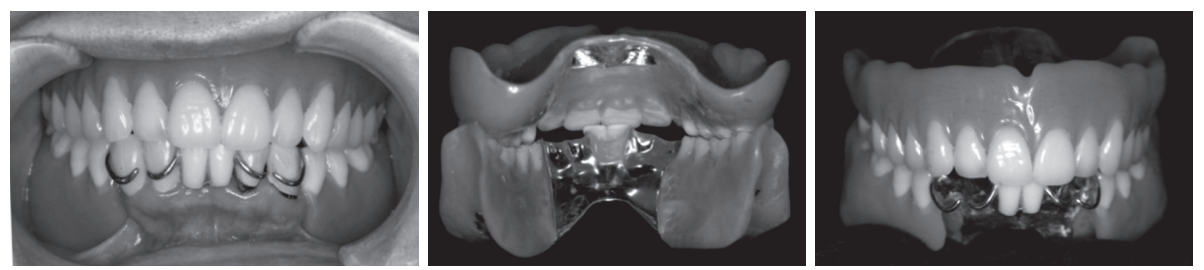

図 4 New dentures and intraoral views after prosthetic treatment 治療後の新義歯と口腔内写真

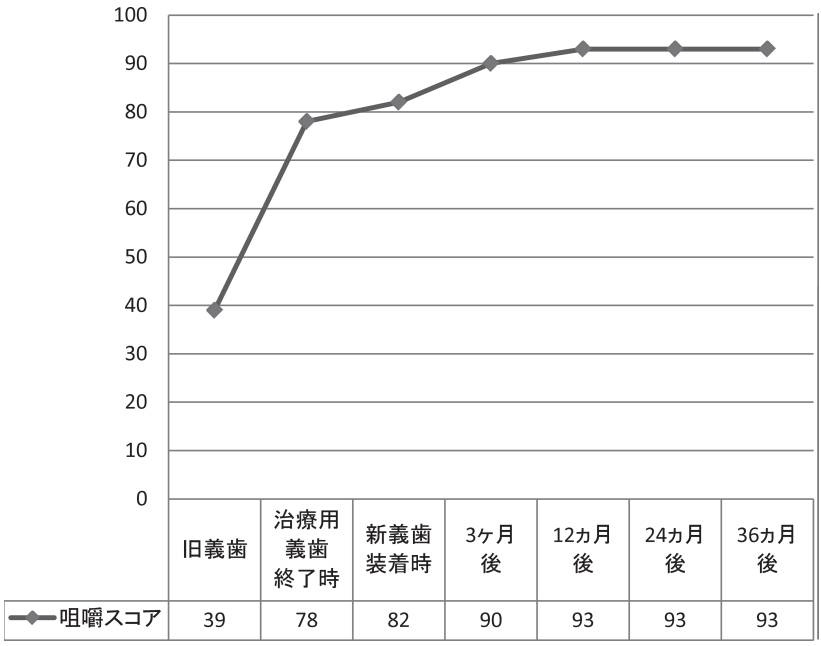

図 5 Masticatory score 咀嚼スコア
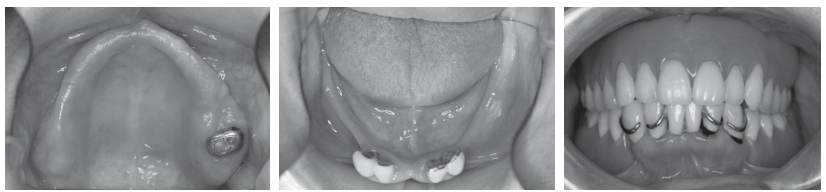

図 6 Intraoral views at 3 years follow-up examination after prosthodontic treatment 補綴治療終了後 3 年経過時の口腔内

を付与した。

上顎義歯は透明レジンにて治療用義歯を，下顎は $\overline{32}$ $\overline{23}$ に両翼鉤，直接維持装置にリンガルプレートを付 与した金属床義歯を装着した（図 2).

「イー，ウー，オー」「モグモグ」「ゴークーン：長く 時間をかけて與下運動」に加え「毎秒 3 回のライトタ ッピングを 10 回」を 1 セットとして，1 日 5 回を目標 にすることを患者に説明しリハビリトレーニングを開始 した。 また，軟性裏装材にて義歯辺緑と研磨面を中心に 各小帯との関係を観察しながら筋圧形成を行い, さらに $\overline{3} \mid 3$ に咬合を付与し下顎位の安定を図った。その後 6 の近心㚘側根が破折したため抜歯を行った。そして治療
開始 6 力月後，㚘筋ならびに口腔周囲筋と舌によるニ ユートラルゾーンおよび咬合平衡か確立し，上下顎義歯 が安定した。ゴシックアーチにてタッピングおよびアペ ックスの位置を確認後, 上顎義歯の機能印象を行った(図 3)。上顎新義歯には治療用義歯と同じ咬合，形態を再 現し金属床にて製作した（図 4)。

現在残存歯および上下顎義歯のメインテナンスを半年 おきに行っているが，咀嚼スコア ${ }^{5)}$ も旧義歯 39 から 93 と顕著な増加を示し, ピーナッツによる咀嚼テスト においても良好な結果となった（図 $5 〜 7$ ).

\section{IV. 考 察}

本症例において，治療用義歯を用いてデンチャースペ 一スを改善, 維持・支持を確立し，下顎両側犬歯を上顎 義歯に咬合させて下顎位を安定化させた，上下顎の高度 な顎堤吸収がある場合の機能圧に対して, 口腔周囲筋(口 輪筋，煩筋，オトガイ筋，上咽頭収縮筋など）と舌のリ ハビリトレーニングを行い筋平衡，咬合平衡が確立し審 美性と咀嚼機能の改善が認められた。これは機能時の筋 形態が上下顎義歯に調和したことによるものと考えられ る(図 8).

今後も残存歯, 下顎位，上下顎義歯の維持，安定を中 心に定期的なメインテナンスを行い, 注意深く経過を観 察していくことが必要であると考える。

\section{V. 結 論}

コンビネーションシンドローム症例に対して，煩筋の 走行形態と筋線維特性を考慮した上顎総義歯をリハビリ トレーニング後に装着することに加えてニュートラルゾ ーンテクニックを応用した下顎両側遊離端義歯を装着す ることで, 下顎位の安定, 上下顎義歯の維持, 安定が得 られ咀嚼障害や審美障害が改善されたものと考えられる。 

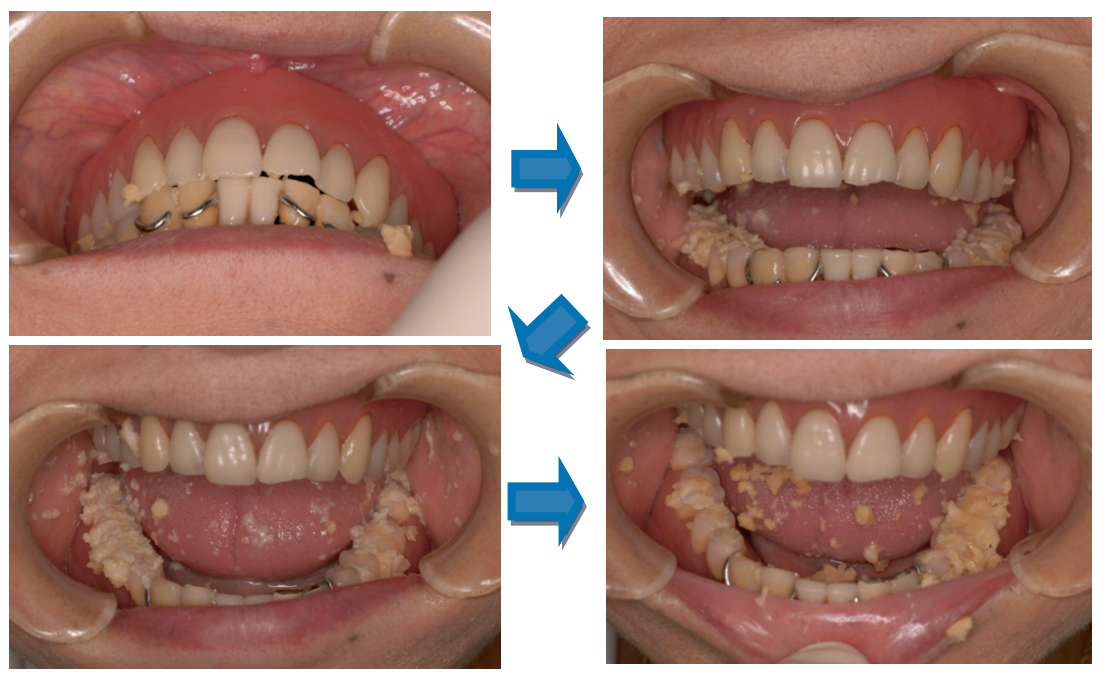

図 7 Mixing ability test (peanut) 咀嚼テスト（ピーナッッ）
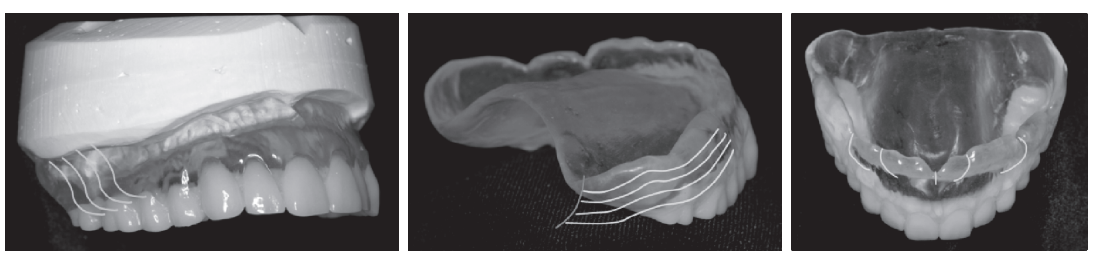

図 8 Running morphology of buccinator muscle 㚘筋の走行形態

謝 辞

稿を終えるに臨み，ご指導，ご校閲いただいた日本歯 科大学生命歯学部歯科補綴学第 1 講座主任の小林義典教 授，またご教示いただいた同講座の志賀 博教授に深謝 いたします。

\section{文献}

1) Kelly E. Changes caused by a mundibular removable partial denture opposing a maxillary complete denture. J Prosthet Dent 1972; 27: 140150.

2) Watt DM, Macgregor AR (小林義典, 鳥居健吾訳). パーシャルデンチャーの設計, 東京 : 医歯薬出版; 1986, 19-20.
3）阿部伸一，井出吉信ほか. ヒト㚘筋の走行形態と筋線維 特性。補綴誌 2002; 46 (107 回特別号)：80.

4) Watt DM, Macgregor AR (小林義典, 鳥居健吾, 田 中 武訳)。コンプリートデンチャーの設計，東京：医歯 薬出版；1979, 4-352.

5）平井敏博. 健康科学を基盤とした歯科補経学の構築. 咬合· 咀嚼が創る健康長寿の実現へ向けて。補綴誌 2007; 51： 691-698.

著者連絡先：上濱 正

干 330-4115 茨城県土浦市藤沢 583-1

TEL: 029-862-5032

FAX: 029-862-1513

E-mail: akiue@it4.so-net.ne.jp 